\title{
Clinical importance of duodenal recesses with special reference to internal hernias
}

\author{
Shivpal V. Tambe ${ }^{1}$, Kum Kum Rana², Arun Kakar ${ }^{3}$, Satish Aggarwal ${ }^{4}$, Anil Aggrawal ${ }^{5}$, Smita Kakar $^{2}$, \\ Nitinkumar Borkar6
}

\begin{abstract}
${ }^{1}$ Department of Anatomy, Government Medical College, Nagpur, India 2Department of Anatomy, Maulana Azad Medical College, New Delhi, India ${ }^{3}$ Department of General Surgery, Maulana Azad Medical College, New Delhi, India ${ }^{4}$ Department of Pediatric Surgery, Maulana Azad Medical College, New Delhi, India ${ }^{5}$ Department of Forensic Medicine and Toxicology, Maulana Azad Medical College, New Delhi, India

${ }^{6}$ Department of Pediatric Surgery, All India Institute of Medical Sciences, Raipur, India
\end{abstract}

Submitted: 29 May 2011

Accepted: 12 July 2011

Arch Med Sci 2017; 13, 1: 148-156

DOI: 10.5114 /aoms.2017.64717

Copyright (c) 2016 Termedia \& Banach

\section{Abstract}

Introduction: The detailed knowledge of the peritoneal recesses has great significance with respect to internal hernias. The recesses are usually related to rotation and adhesion of abdominal viscera to the posterior abdominal wall and/or the presence of retroperitoneal vessels which raises the serosal fold. The duodenal recesses are usually related to the $3^{\text {rd }}$ and $4^{\text {th }}$ parts of the duodenum. Internal hernias with respect to these recesses are difficult to diagnose clinically and usually noticed at the time of laparotomy. So, the knowledge of these recesses can be valuable to abdominal surgeons.

Material and methods: The present study was conducted in 100 cases including 10 cadavers, 45 post mortem cases and 45 cases undergoing laparotomy.

Results: We found superior and inferior duodenal recesses in $28 \%$ and $52 \%$ respectively, paraduodenal in $12 \%$, mesentericoparietal in $3 \%$, retroduodenal in $2 \%$ and duodenojejunal in $18 \%$ of cases. Two abnormal duodenojejunal recesses were found, one on the right (instead of the left) of the abdominal aorta, and in the other the opening was directed upwards instead of downwards. The incidence of internal hernias was $3 \%$.

Conclusions: Thus it was observed that there is low incidence of superior and inferior duodenal recesses, and high incidence of paraduodenal recess. The abnormal recesses might be due to malrotation of the gut. In laparotomy cases, the internal hernia was noticed when the abdomen was opened for intestinal obstruction. The incidence of internal hernia was found to be high.

Key words: peritoneal recesses, internal hernias, retroperitoneal vessels.

\section{Introduction}

The present study was carried out to observe the duodenal recesses or fossae and their association with internal hernias, since there is a paucity of data on this subject in the Indian population. The duodenal recesses studied were superior, inferior, paraduodenal, mesentericoparietal, retroduodenal and duodenojejunal. The peritoneal recesses are usually related to rotation of the gut and adhesion of abdominal viscera to the posterior abdominal wall during fetal development, and/or the

\author{
Corresponding author: \\ Dr. Shivpal V. Tambe, \\ Assist. Prof. \\ Department of Anatomy \\ Government Medical College \\ Nagpur 440009, India \\ Phone: +91 8888954813 \\ E-mail: shivtambe@gmail. \\ com
}


presence of retroperitoneal vessels which raise serosal folds. These recesses, therefore, are regarded as congenital and have been considered clinically and surgically as sites for internal abdominal hernias [1, 2]. Some of the peritoneal recesses are well known (such as the superior duodenal, the inferior duodenal, and the duodenojejunal) and have been described in the literature. Other recesses such as retroduodenal, mesenterico-parietal, and paraduodenal are less commonly observed. They are clinically relevant as internal $a b-$ dominal hernias may develop inside them. These hernias are difficult to diagnose clinically as they are usually noticed at the time of laparotomy [3, 4]. Thus, the topography of these recesses is very valuable to abdominal surgeons.

Due to the complex nature of the rotation of the gut and resorption of the mesentery, these recesses may enlarge or recede, and individual variations may lead to the development of different recesses in this area. The normal coalescence of the duodenum to the parietal peritoneum occurs between its $3^{\text {rd }}$ and $4^{\text {th }}$ parts, and at the level of the duodenojejunal flexure, by means of two serous folds, inferior and superior. The majority of internal hernias result from congenital anomalies of intestinal rotation and peritoneal attachment $[5,6]$.

There has been no descriptive study encompassing all the duodenal recesses. The present study is an attempt to describe these topographically and their association with internal abdominal hernias.

\section{Material and methods}

The present study was conducted in 100 cases including 10 cadavers, 45 bodies undergoing post-mortem and 45 patients undergoing laparotomy for different indications in the Department of Anatomy, Department of Forensic Medicine and Toxicology and Department of General and Pediatric Surgery, Maulana Azad Medical College and associated Lok Nayak Hospital, New Delhi.
The recesses were observed for: 1) position and direction of the opening, 2) depth and width, 3) related structures (normal and anomalous) and 4) presence of internal hernia, if any.

This study is a part of a post-graduate thesis which has been undertaken after the approval and permission of the thesis committee (Maulana Azad Medical College and associated Lok Nayak Hospital, New Delhi), and there is no ethical issue.

In cadavers, all the observations were made once the abdomen was opened for dissection for academic purposes, and these were taken before the disturbance of the peritoneum by students. The greater omentum and transverse mesocolon were pulled upwards and coils of jejunum along with its mesentery were pulled downwards and to the right side so as to expose the duodenojejunal junction, and the third and fourth part of the duodenum were identified. In post-mortem cases, all the observations were made before removal of abdominal viscera for post mortem examination.

In laparotomy cases, the measurements were made by the operating surgeon in consultation with the investigator. The measurements were made either by Vernier caliper or by measuring tape.

\section{Results}

The incidence of duodenal recesses in our study is tabulated in Table I. The other observations are tabulated in Tables II-VII.

In these the numbers 1 to 100 are: $1-10$ were cadavers, 11-55 were post-mortem cases, 56-100 were laparotomy cases (56-90 pediatric cases and 90-100 adult cases).

Two abnormal duodenojejunal recesses were found, one on the right (instead of the left) of the abdominal aorta, and in the other the opening was directed upwards instead of downwards.

\section{Discussion}

The peritoneum is the largest and most complexly arranged serous membrane in the body. Its

Table I. Incidence of duodenal recesses

\begin{tabular}{|lcccc|}
\hline Duodenal recesses & $\begin{array}{c}\mathrm{C}(\mathrm{N}=10) \\
n(\%)\end{array}$ & $\begin{array}{c}\mathrm{P}(\mathrm{N}=45) \\
n(\%)\end{array}$ & $\begin{array}{c}\mathrm{L}(\mathrm{N}=45) \\
n(\%)\end{array}$ & $\begin{array}{c}\text { Total incidence } \\
(N=100) \\
n(\%)\end{array}$ \\
\hline Superior duodenal & $2(20)$ & $14(31.11)$ & $12(26.66)$ & $28(28)$ \\
\hline Inferior duodenal & $6(60)$ & $25(55.55)$ & $21(46.66)$ & $52(52)$ \\
\hline Paraduodenal & $2(20)$ & $8(17.77)$ & $2(4.44)$ & $12(12)$ \\
\hline Mesentericoparietal & $2(20)$ & $0(0)$ & $10(22.22)$ & $18(18)$ \\
\hline Duodenojejunal & $2(20)$ & $6(13.33)$ & $0(0)$ & $2(2)$ \\
\hline Retroduodenal & $1(10)$ & $1(2.22)$ & & $3(3)$ \\
\hline
\end{tabular}


reflections form ligaments, mesenteries, omenta and the route of natural spread of peritoneal fluid. These also serve as boundaries for disease processes and are conduits for disease spread. Computed tomography and to a lesser extent sonography and magnetic resonance (MR) imaging allow the accurate examination of the complex anatomy of the peritoneal cavity, which is the key to understanding the pathological processes affecting it. Hence it is very important to know the peritoneal recesses, their relations and the internal hernias $[1,7]$.

In certain parts of the abdomen, peritoneal folds may sometimes be found which bind fosse or recesses of the peritoneal cavity. These recesses are of surgical importance since they may become the site of internal herniae, that is, a segment of intestine may enter a recess and may be constricted and get strangulated by the peritoneal fold guarding the entrance to the recess. Since the

Table II. Superior duodenal recess

\begin{tabular}{|c|c|c|c|c|c|}
\hline S. No. & Position and direction & Depth $[\mathrm{cm}]$ & Width $[\mathrm{cm}]$ & $\begin{array}{l}\text { Related structures } \\
\text { (normal) }\end{array}$ & $\begin{array}{l}\text { Related structures } \\
\text { (anomalous) }\end{array}$ \\
\hline 1 & $\begin{array}{l}\text { Behind D-J fold, Lt of } 4^{\text {th }} \text { part } \\
\text { of duodenum, directed } \downarrow\end{array}$ & 2.0 & 1.2 & - & - \\
\hline 4 & do & 2.4 & 1.4 & - & - \\
\hline 13 & do & 2.3 & 1.8 & - & - \\
\hline 15 & do & 3 & 2 & - & - \\
\hline 18 & do & 3 & 1.7 & - & - \\
\hline 21 & do & 2 & 1.4 & - & - \\
\hline 26 & do & 3 & 1.5 & - & - \\
\hline 29 & do & 3.2 & 1.2 & - & - \\
\hline 32 & do & 2.5 & 1.2 & - & - \\
\hline 36 & do & 2.5 & 1.2 & - & - \\
\hline 38 & do & 3.5 & 2 & - & - \\
\hline 42 & do & 2.5 & 1.2 & - & - \\
\hline 44 & do & 2.5 & 1.2 & - & - \\
\hline 51 & do & 3.5 & 1.2 & - & - \\
\hline 53 & do & 3.5 & 1.2 & - & - \\
\hline 55 & do & 2.5 & 1.2 & & \\
\hline 57 & do & 1.5 & 0.6 & - & - \\
\hline 62 & do & 1.5 & 0.6 & - & - \\
\hline 63 & do & 2.5 & 1.4 & - & - \\
\hline 64 & do & 2.5 & 1.2 & - & - \\
\hline 65 & do & 1.0 & 0.5 & - & - \\
\hline 66 & do & 3.0 & 2.0 & - & - \\
\hline 70 & do & 3.0 & 1.8 & - & - \\
\hline 75 & do & 3.0 & 1.8 & - & \\
\hline 77 & do & 3.5 & 1.8 & - & - \\
\hline 80 & do & 3.0 & 1.4 & & \\
\hline 84 & do & 2.0 & 0.8 & - & - \\
\hline 95 & do & 2.5 & 1.2 & & \\
\hline
\end{tabular}

These are the observations done in individual case. S. No. 1-10: cadavers, S. No. 11-55: post-mortem cases, S. No. 56-100: laparotomy cases (56-90 paediatric cases \& 90-100 adult cases), D-J fold - duodenojejunal fold. Lt - left, $\downarrow-$ downwards, do - same. 
Table III. Inferior duodenal recess

\begin{tabular}{|c|c|c|c|c|c|}
\hline S. No. & Position and direction & Depth $[\mathrm{cm}]$ & Width $[\mathrm{cm}]$ & $\begin{array}{l}\text { Related structures } \\
\text { (normal) }\end{array}$ & $\begin{array}{l}\text { Related structures } \\
\text { (anomalous) }\end{array}$ \\
\hline 3 & $\begin{array}{l}\text { Behind DMC fold, Lt of } 4^{\text {th }} \text { part } \\
\text { of duodenum, directed } \uparrow\end{array}$ & 3.6 & 1.0 & - & - \\
\hline 4 & do & 3.0 & 1.0 & - & - \\
\hline 5 & do & 4.0 & 2.0 & - & - \\
\hline 6 & do & 3.6 & 1.5 & - & - \\
\hline 7 & do & 3.5 & 2.0 & - & \\
\hline 10 & do & 4.0 & 3.0 & - & - \\
\hline 11 & do & 4.0 & 1.5 & - & - \\
\hline 13 & do & 4.2 & 1.2 & - & - \\
\hline 14 & do & 3.5 & 1.2 & - & - \\
\hline 17 & do & 4.7 & 2.6 & - & - \\
\hline 19 & do & 5.0 & 2.9 & - & - \\
\hline 22 & do & 4.6 & 2.9 & - & - \\
\hline 23 & do & 4.9 & 2.6 & - & - \\
\hline 26 & do & 4.0 & 2.0 & - & - \\
\hline 27 & do & 3.5 & 2.0 & - & - \\
\hline 29 & do & 4.0 & 1.6 & - & - \\
\hline 30 & do & 2.0 & 1.2 & - & - \\
\hline 31 & do & 3.5 & 2.0 & - & - \\
\hline 32 & do & 3.0 & 1.8 & - & - \\
\hline 34 & do & 3.5 & 1.8 & - & - \\
\hline 35 & do & 2.5 & 1.2 & - & - \\
\hline 36 & do & 4.0 & 2.5 & - & - \\
\hline 37 & do & 3.5 & 1.8 & - & - \\
\hline 38 & do & 4.0 & 2.9 & - & - \\
\hline 40 & do & 4.0 & 2.0 & - & - \\
\hline 42 & do & 4.0 & 2.0 & - & - \\
\hline 44 & do & 4.0 & 2.5 & - & - \\
\hline 45 & do & 2.0 & 1.2 & - & - \\
\hline 50 & do & 4.0 & 1.8 & - & - \\
\hline 51 & do & 4.0 & 2.5 & - & - \\
\hline 54 & do & 4.0 & 1.2 & - & - \\
\hline 57 & do & 2.0 & 1.0 & - & - \\
\hline 60 & do & 3.0 & 1.2 & - & - \\
\hline 62 & do & 3.0 & 1.4 & - & - \\
\hline 63 & do & 3.5 & 1.8 & - & - \\
\hline 64 & do & 3.0 & 1.4 & - & - \\
\hline 65 & do & 1.8 & 0.8 & - & - \\
\hline 69 & do & 4.0 & 2.2 & - & - \\
\hline 70 & do & 3.0 & 2.0 & - & - \\
\hline 71 & do & 4.0 & 2.1 & - & - \\
\hline 72 & do & 4.0 & 2.0 & - & - \\
\hline 73 & do & 3.0 & 1.8 & - & - \\
\hline 75 & do & 4.0 & 2.2 & - & - \\
\hline 76 & do & 4.0 & 1.8 & - & - \\
\hline 80 & do & 4.0 & 1.8 & - & - \\
\hline
\end{tabular}


Table III. Cont.

\begin{tabular}{|lccccc|}
\hline S. No. & Position and direction & Depth $[\mathrm{cm}]$ & Width $[\mathrm{cm}]$ & $\begin{array}{c}\text { Related structures } \\
\text { (normal) }\end{array}$ & $\begin{array}{c}\text { Related structures } \\
\text { (anomalous) }\end{array}$ \\
\hline 81 & do & 2.0 & 1.2 & - & - \\
\hline 82 & do & 1.4 & 1.2 & - & - \\
\hline 84 & do & 2.4 & 1.0 & - & - \\
\hline 85 & do & 3.5 & 1.6 & - & - \\
\hline 95 & do & 3.6 & 2.0 & - & Loop of jejunum \\
\hline 97 & do & 3.5 & 1.6 & - & - \\
\hline 100 & do & 3.6 & 1.4 & - & - \\
\hline
\end{tabular}

These are the observations done in individual case. S. No. 1-10: cadavers, S. No. 11-55: post-mortem cases, S. No. 56-100: laparotomy cases (56-90 paediatric cases \& 90-100 adult cases), DMC - duodenomesocolic fold, Lt - left, $\uparrow$ - upwards, do - same.

Table IV. Paraduodenal recess

\begin{tabular}{|c|c|c|c|c|c|c|}
\hline S. No. & Position and direction & Depth $[\mathrm{cm}]$ & Width $[\mathrm{cm}]$ & $\begin{array}{l}\text { Related } \\
\text { structures } \\
\text { (normal) }\end{array}$ & $\begin{array}{c}\text { Related } \\
\text { structures } \\
\text { (anomalous) }\end{array}$ & $\begin{array}{l}\text { Internal } \\
\text { hernias }\end{array}$ \\
\hline 1 & $\begin{array}{c}\text { Behind the paraduodenal fold, } \\
\text { Lt of } 4^{\text {th }} \text { part of duodenum, } \\
\text { directed Rt } \uparrow\end{array}$ & 2.5 & 3.9 & IMV & $\begin{array}{l}\text { Ascending } \\
\text { branch of left } \\
\text { colic artery }\end{array}$ & - \\
\hline 9 & Directed RT \& $\downarrow$ & 2.5 & 3.0 & IMV & - & - \\
\hline 24 & $\begin{array}{c}\text { Behind the paraduodenal fold, } \\
\text { Lt of } 4^{\text {th }} \text { part of duodenum, } \\
\text { directed Rt } \uparrow\end{array}$ & 4.6 & 2.5 & IMV & $\begin{array}{l}\text { Ascending } \\
\text { branch of left } \\
\text { colic artery }\end{array}$ & $\begin{array}{l}\text { Yes, loop of } \\
\text { jejunum }\end{array}$ \\
\hline 25 & Directed RT \& $\downarrow$ & 4.0 & 2.5 & IMV & - & - \\
\hline 26 & do & 4.0 & 2.0 & - & - & - \\
\hline 27 & do & 3.5 & 2.0 & & - & - \\
\hline 28 & do & 2.5 & 1.0 & IMV & $\begin{array}{c}\text { Ascending } \\
\text { branch of Lt } \\
\text { of of Lt colic } \\
\text { artery }\end{array}$ & - \\
\hline 33 & do & 4.5 & 2.5 & IMV & - & $\begin{array}{l}\text { Yes, loop of } \\
\text { jejunum }\end{array}$ \\
\hline 37 & do & 4.5 & 2.5 & IMV & - & - \\
\hline 46 & do & 2.5 & 1.2 & IMV & - & - \\
\hline 74 & do & 2.0 & 1.2 & IMV & - & - \\
\hline 96 & do & 2.4 & 2.0 & IMV & - & \\
\hline
\end{tabular}

These are the observations done in individual case. S. No. 1-10: cadavers, S. No. 11-55: post-mortem cases, S. No. 56-100: laparotomy cases (56-90 paediatric cases \& 90-100 adult cases), IMV - inferior mesenteric vein, Lt - left, Rt - right, $\downarrow-$ downwards, $\uparrow-$ upwards, do-same.

entrance to the recess may need to be cut to relieve strangulation and allow the gut to be drawn out of the recess, it is necessary to note whether the fold is significantly vascularised [8].

The superior duodenal recess (recessus duodeno-mesocolicus superior) was found in $28 \%$ of cases, compared to $40 \%$ to $50 \%$ found by other researchers [4, 8-11], and was associated with inferior duodenal recess in $75 \%$ of cases. It was located on the left side of the $4^{\text {th }}$ part of the duodenum, and the orifice was directed downwards. Its depth and width were $1-3.5 \mathrm{~cm}$ and $0.5-2.0 \mathrm{~cm}$ respectively (Figure 1).

The inferior duodenal recess (fossa duodeno-jejunalis of Treitz; recessus duodeno-mesocolicus inferior of Brosike) was observed in $52 \%$ of cases as against $70-75 \%$ reported by other workers [4, 8-11]. It was situated on the left of the ascending $\left(4^{\text {th }}\right)$ part of the duodenum, and the opening was directed upwards. Maximum depth and width were $5.0 \mathrm{~cm}$ and $2.9 \mathrm{~cm}$ respectively (Figure 2). Also, in one of the cases, we found a common opening for both superior and inferior recesses, a finding not reported earlier (Figure 3).

The genesis of superior and inferior duodenal folds has been described differently by various 
Table V. Duodenojejunal recess

\begin{tabular}{|c|c|c|c|c|c|}
\hline S. No. & Position and direction & Depth $[\mathrm{cm}]$ & Width $[\mathrm{cm}]$ & $\begin{array}{l}\text { Related structures } \\
\text { (normal) }\end{array}$ & $\begin{array}{c}\text { Related } \\
\text { structures } \\
\text { (anomalous) }\end{array}$ \\
\hline 9 & $\begin{array}{c}\text { On the Lt side of abdominal aorta } \\
\text { between D-J fold \& root of transverse } \\
\text { mesocolon, orifice is circular \& directed } \\
\downarrow \downarrow R \text { Rt }\end{array}$ & 3.0 & 2.2 & $\begin{array}{l}\text { Above pancreas, } \\
\text { on Lt by Lt kidney } \\
\& \text { LRV inferiorly }\end{array}$ & - \\
\hline 10 & Opening directed $\uparrow \& \mathrm{Lt}$ & 1.5 & 3.0 & do & - \\
\hline 43 & do & 3.5 & 1.5 & do & - \\
\hline 46 & do & 3.0 & 1.2 & do & - \\
\hline 47 & do & 3.5 & 1.2 & do & - \\
\hline 48 & do & 2.5 & 1.0 & do & - \\
\hline 49 & do & 2.5 & 1.2 & do & - \\
\hline 52 & do & 3.0 & 1.2 & do & - \\
\hline 58 & do & 2.0 & 1.0 & do & - \\
\hline 59 & do & 2.0 & 0.8 & do & - \\
\hline 61 & do & 2.0 & 1.2 & do & - \\
\hline 68 & do & 3.0 & 1.2 & do & - \\
\hline 73 & do & 2.0 & 1.0 & do & - \\
\hline 78 & do & 3.0 & 1.2 & IMV in Lt fold & - \\
\hline 79 & do & 3.5 & 2.0 & $\begin{array}{l}\text { Above pancreas, } \\
\text { on Lt by Lt kidney } \\
\text { \& LRV inferiorly }\end{array}$ & - \\
\hline 83 & do & 3.0 & 1.2 & do & - \\
\hline 88 & do & 2.5 & 1.0 & IMV in Lt fold & - \\
\hline 89 & do & 2.2 & 0.4 & do & - \\
\hline
\end{tabular}

These are the observations done in individual case. S. No. 1-10: cadavers, S. No. 11-55: post-mortem cases, S. No. 56-100: laparotomy cases (56-90 paediatric cases \& 90-100 adult cases), D-J fold - duodenojejunal fold, IMV-inferior mesenteric vein, LRV - left renal vein, Lt - left, Rt-right, $\downarrow$-downwards, $\uparrow$ - upwards, do - same.

Table VI. Mesenterico-parietal recess

\begin{tabular}{|lccccc|}
\hline S. No. & Position and direction & Depth $[\mathrm{cm}]$ & Width $[\mathrm{cm}]$ & $\begin{array}{c}\text { Related structures } \\
\text { (normal) }\end{array}$ & $\begin{array}{c}\text { Related structures } \\
\text { (anomalous) }\end{array}$ \\
\hline 1 & $\begin{array}{c}\text { Below the 3 }{ }^{\text {rd }} \text { part of duodenum, } \\
\text { behind first part of mesojejunum, } \\
\text { directed to Lt }\end{array}$ & 3.0 & 2.5 & $\begin{array}{c}\text { Superior } \\
\text { mesenteric vessels }\end{array}$ & - \\
\hline 8 & do & 3.2 & 2.5 & $\begin{array}{c}\text { Superior } \\
\text { mesenteric vessels }\end{array}$ & - \\
\hline 90 & do & 4.0 & 2.5 & $\begin{array}{c}\text { Superior } \\
\text { mesenteric vessels }\end{array}$ & - \\
\hline
\end{tabular}

These are the observations done in individual case. S. No. 1-10: cadavers, S. No. 11-55: post-mortem cases, S. No. 56-100: laparotomy cases (56-90 paediatric cases \& 90-100 adult cases), Lt - left, do-same.

researchers [4]. According to Treitz, these are traction folds formed during development, due to dragging of the intestine and displacement of the caecum and ascending colon to the right side, whereas Waldeyer describes them as vascular folds due to the inferior mesenteric vein.
Treves suggested that the inferior duodenal fold is a remnant of the mesoduodenum, but Told describes these as fusion folds, caused by the process of physiological adhesions between the original left, afterwards anterior surface of the ascending part of the duodenum and the right 
Table VII. Retroduodenal recess

\begin{tabular}{|lccccc|}
\hline S. No. & Position and direction & Depth $[\mathrm{cm}]$ & Width $[\mathrm{cm}]$ & $\begin{array}{c}\text { Related structures } \\
\text { (normal) }\end{array}$ & $\begin{array}{c}\text { Related structures } \\
\text { (anomalous) }\end{array}$ \\
\hline 10 & $\begin{array}{c}\text { Behind the } 3^{\text {rd }} \& 4^{\text {th }} \text { part of } \\
\text { duodenum, in front of abdominal } \\
\text { aorta. opening directed Lt \& } \downarrow\end{array}$ & 9.0 & 4.0 & $\begin{array}{c}\text { Abdominal aorta } \\
\text { deep in the recess }\end{array}$ & - \\
\hline 48 & $\begin{array}{c}\text { Behind the } 3^{\text {rd }} \& 4^{\text {th }} \text { part of } \\
\text { duodenum, in front of abdominal } \\
\text { aorta. opening directed Lt \& } \downarrow\end{array}$ & 6.0 & 3.0 & $\begin{array}{c}\text { Abdominal aorta } \\
\text { deep in the recess }\end{array}$ & - \\
\hline
\end{tabular}

These are the observations done in individual case. S. No. 1-10: cadavers, S. No. 11-55: post-mortem cases, S. No. 56-100: laparotomy cases (56-90 paediatric cases \& 90-100 adult cases), Lt - left, $\downarrow-$ downwards.

or anterior surface of the descending mesocolon [4]. Several authors [1, 5, 9, 12] have observed peritoneal fossae, contributing to the discussion about their origin and relationship to congenital or acquired internal abdominal hernias. The process of formation of peritoneal fossae is not easy to explain. According to Ancel and Cavaillon [5], the normal coalescence of the duodenum to the posterior parietal peritoneum would occur between its third and fourth part, and at the level of the duodeno-jejunal flexure, by means of two (inferior and superior) serous folds. These

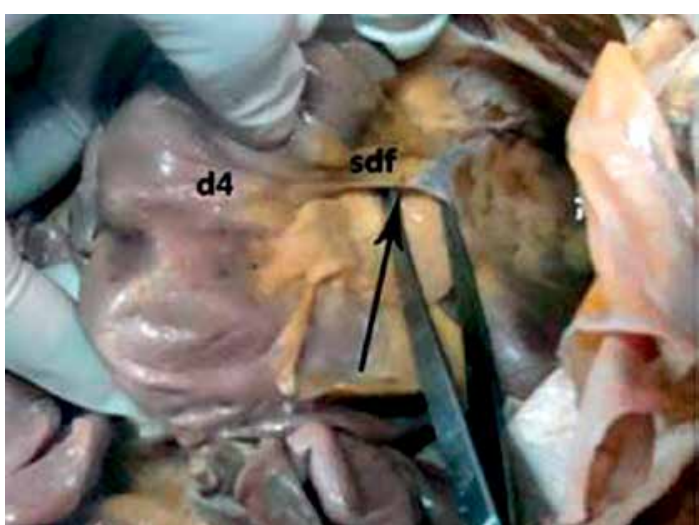

Figure 1. Superior duodenal recesses

$d 4$ - ascending part of duodenum, sdf - superior duodenal fold, arrow in the superior duodenal recess.

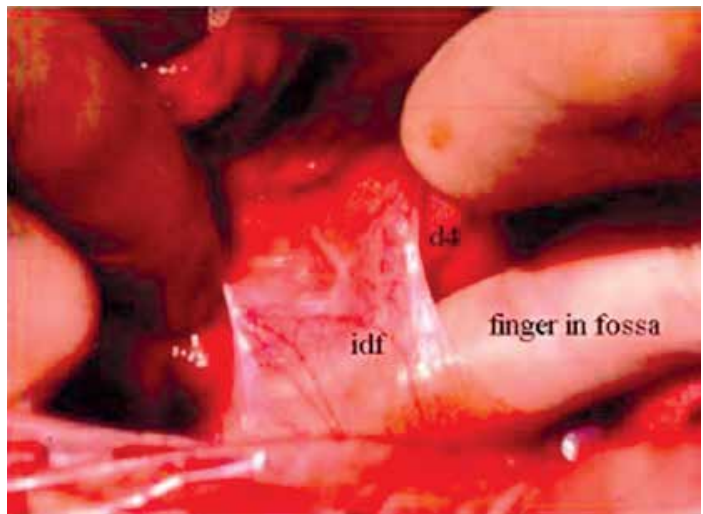

Figure 2. Inferior duodenal recesses

d4 $-4^{\text {th }}$ part of the duodenum, idf - inferior duodenal fold, finger in inferior duodenal recess. connect the duodenum horizontally to the serosa. In the meantime, the folds would also grow vertically: the inferior upward and the superior downward. In this way the inferior and superior fossae are generated.

These authors [5] noted that the inferior duodenal fold was better developed than the superior one. The incidence of inferior duodenal fossa $(52 \%)$ is almost double that of superior duodenal fossa $(28 \%)$ found in the present study, which is a very significant difference. In our study, we found a common opening for the superior and inferior duodenal fossae in one of the cases. This can be explained on the basis of vertical growth of the two folds, and these folds might have grown extensively towards each other and fused laterally, thus forming a common opening.

Paraduodenal fossa (recess venosus, fossa of Landzert) originates as congenital peritoneal anomaly owing to failure of mesenteric fusion with the parietal peritoneum. There is also an associated abnormal rotation during imprisonment of the small intestine beneath the developing colon [6]. In the present study a paraduodenal recess was found in $12 \%$ of cases, which is contrary to many studies [ 2 , $4,8,11]$ where it was $2 \%$. Each was situated on the left side of the $4^{\text {th }}$ part of the duodenum, and the

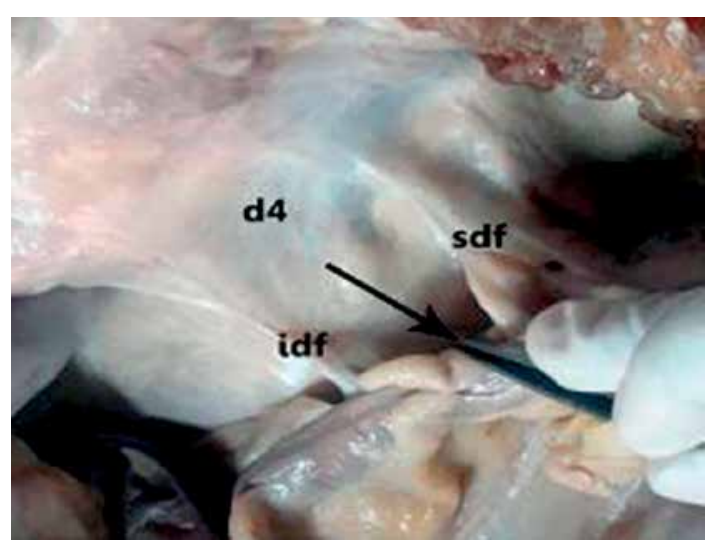

Figure 3. Common opening for both superior and inferior duodenal recesses

$d 4$ - ascending part of duodenum, sdf - superior duodenal fold, idf - inferior duodenal fold, arrow in the common opening for both the recesses. 


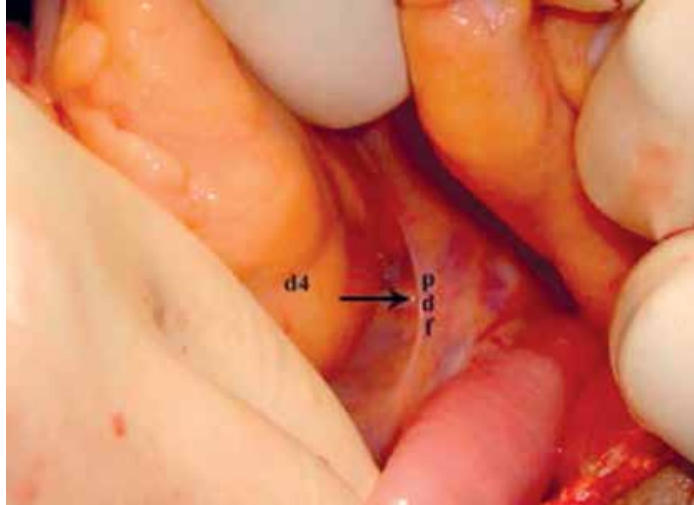

Figure 4. Paraduodenal recesses

$d 4$ - ascending part of duodenum, pdf - paraduodenal fold, arrow in the paraduodenal recess.

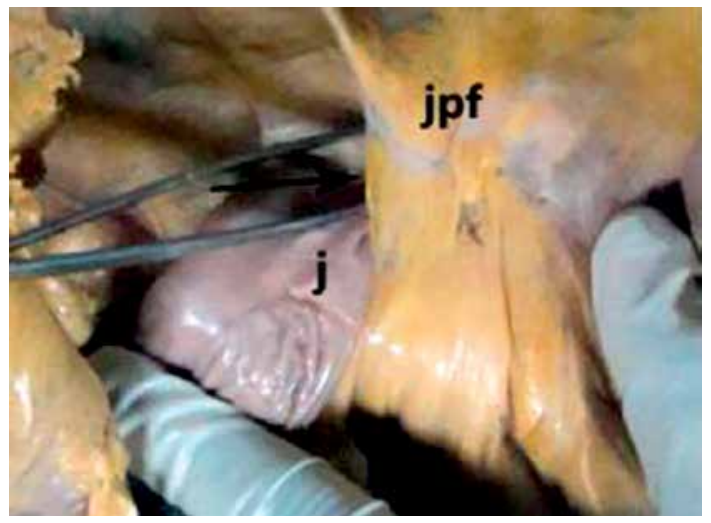

Figure 6. Duodenojejunal recesses

$j$ - jejunum, jpf-jejunoparietal fold, arrow in the duo denojejunal recess.

opening was directed downwards and to the right - a finding similar to that of other authors $[2,4,8$, 12-14]. Its depth was 2 to $4.5 \mathrm{~cm}$ and width 1 to $4 \mathrm{~cm}$ (Figure 4). We found its association with the mesentericoparietal recess in one instance and the inferior duodenal recess in three cases.

The genesis of the paraduodenal fossa might be due to raising of the serosal fold(s) by the underlying inferior mesenteric vein and/or the ascending branch of the left colic artery $[3,4]$. In the present study, we found two separate paraduodenal recesses, one due to the ascending branch of the left colic artery (arterial recess) and the other due to the inferior mesenteric vein (venous recess) (Figure 5). This hypothesis has been described by other authors $[1,5,9]$. Paraduodenal hernia was observed in $2(16.66 \%)$ cases of the total number of paraduodenal fossae found in our study. Also, both of these hernias were seen only on the left side.

Mesentericoparietal recess (of Waldeyer) was observed in the first part of the mesojejunum in our study. It was immediately behind the superior mesenteric artery, and just below the $3^{\text {rd }}$ part of the duodenum. It was present in $3 \%$ of cases and

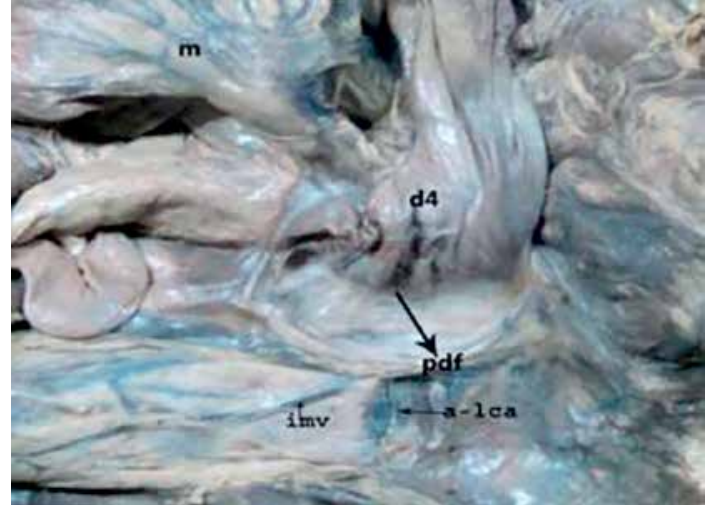

Figure 5. Vessels in paraduodenal fold

$d 4$ - ascending part of duodenum, pdf - paraduodenal fold, imv - inferior mesenteric vein, a-lca - ascending branch of left colic artery, $m$ - the mesentery.

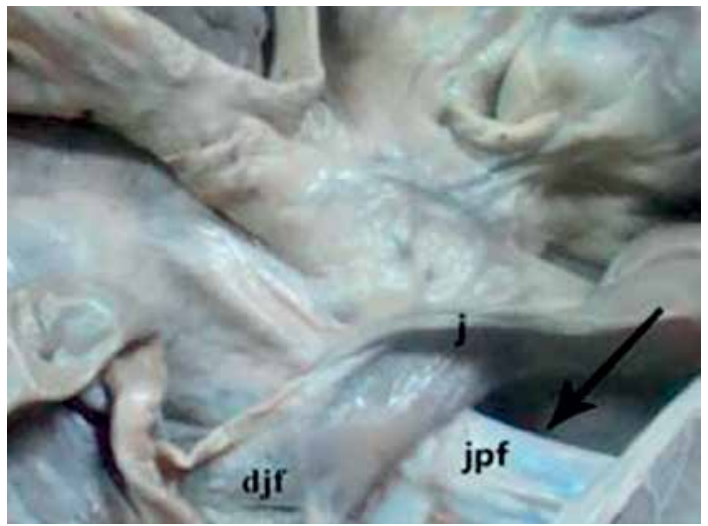

Figure 7. Duodenojejunal recesses

j-jejunum, jpf-jejunoparietal fold, djf-duodenojejunal flexure, arrow in the duodenojejunal recess.

mostly found in adults, in contrast to others [4, 8, 9] who found the prevalence higher in the pediatric age group. This recess was not associated with other duodenal fossae. Its depth and width were $3-4 \mathrm{~cm}$ and $2.5 \mathrm{~cm}$ respectively.

The duodenojejunal fossa (recessus duodenojejunalis superior) was seen by pulling the jejunum downwards and to the right, after the transverse colon was pulled upwards. These were found in $18 \%$ of cases in the present study, quite similar to those reported by other researchers [4, 8]. Their depth and width measured $1.5-3.5 \mathrm{~cm}$ and $0.4-3.0 \mathrm{~cm}$ respectively.

Two abnormal duodenojejunal fossae were found, one on the right side of the abdominal aorta and opening was directed to the right and downwards (Figure 6), and in the other the opening was directed upwards instead of downwards (Figure 7). This might be due to the malrotation of the gut.

Retroduodenal recess was found to be the largest of the duodenal recesses in the present study and was behind the horizontal and the ascending part of the duodenum, in front of the abdominal 
aorta. It was observed in $2 \%$ of cases. In one of the cases, it was extending upwards as far as the duodenojejunal junction. It was $6 \mathrm{~cm}$ and $10 \mathrm{~cm}$ deep and $3 \mathrm{~cm}$ and $4 \mathrm{~cm}$ in width and was bounded on both sides by duodenoparietal folds. Its orifice was facing downwards and to the left.

An internal abdominal hernia is defined as the protrusion of a viscous through a normal or abnormal aperture within the confines of the peritoneal cavity. The hernial orifice may be a preexisting anatomic structure, such as the foramen of Winslow, or a pathologic defect of congenital or acquired origin. The incidence of these hernias is estimated between $0.2 \%$ and $2 \%$ of abdominal hernias, and $0.2 \%$ to $0.9 \%$ of autopsies. These hernias mostly presented as an intestinal obstruction, and diagnosis is usually made at the time of surgery $[3,5$, 6, 15-18].

The role of preoperative radiologic diagnosis of internal hernias has generally not been appreciated. Indeed, in the differential diagnosis of radiographic findings of intestinal obstruction or unusual appearing grouping of bowel loops, "some type of internal hernia" is often loosely entertained without a precise appreciation of types and distinctive findings. Hence, with awareness of the underlying anatomic features of recesses and of the dynamics of intestinal entrapment, the correct diagnosis of an internal hernia can be made [15-22].

We found the incidence of internal hernias quite high in the Indian population, at was around $3 \%$. These were, two left paraduodenal hernias, found in postmortem cases, and one in the inferior duodenal recesses, seen in a laparotomy case. In the case of inferior duodenal hernia, the patient was explored for intestinal obstruction, and it was seen that the jejunal loop was herniated into this fossa and was strangulated.

In conclusion, based on the anatomic findings, these fossae or recesses, because of their size and topography, might play a role in the etiopathogenesis of internal abdominal hernias. Henceforth, the findings of the present study may help the abdominal surgeon to appreciate these recesses, which might prove to be quiet significant in differential diagnosis with cases of intestinal obstruction.

\section{Acknowledgments}

We express our sincerest thanks to the residents of the Anatomy, Forensic Medicine and Toxicology, General and Pediatric Surgery. We are grateful to Dr. A.K. Agarwal, Dean and Dr. J.M. Kaul, Director Professor and Head, Department of Anatomy, Maulana Azad Medical College, New Delhi for their guidance and permission to publish this work. Special thanks to Mrs. Swati Tambe for her unfailing support, guidance and encouragement.

\section{Conflict of interest}

The authors declare no conflict of interest.

\section{References}

1. Barberini F, Carone VS, Caggiati A, Macchiarelli G, Corner S. An unusual peritoneal fossa: anatomic report and clinical implications. Surg Radiol Anat 1999; 21: 287-91.

2. Peltier J, Gars DL, Page C, Yzet T, Launde M. The duodenal fossae: anatomic study and clinical correlations. Surg Radiol Anat 2005; 27: 303-7.

3. Blachar A, Federle MP, Dodson SF. Internal hernia: clinical and imaging findings in 17 patients with emphasis on CT criteria. Radiology 2001; 218: 68-74.

4. Moynihan BGA. The Arris and Gale lectures on the anatomy and surgery of the peritoneal fossae. BMJ 1899; 1: 522-5.

5. Barberini F, Zani A, Ripani M, Di Nitto V, Brunone F. The complex arrangement of an "aorto-jejunal paraduodenal" fossa, as revealed by dissection of human posterior parietal peritoneum. Ann Anat 2007; 189: 299-303.

6. Takeyama N, Gokan T, Ohgiya Y, et al. CT of internal hernias. RadioGraphics 2005; 25: 997-1015.

7. Healy JC, Reznek RH. The peritoneum, mesenteries and omenta: normal anatomy and pathological processes. Eur Radiol 1998; 8: 886-900.

8. Williams PL, Warwick R. Gray's Anatomy. $36^{\text {th }}$ ed. Churchill Livingstone, Edinburgh 1980; 1330-1.

9. Hirasaki S, Koide N, Shima $\mathrm{Y}$, et al. Unusual variant of left paraduodenal hernia herniated into the mesocolic fossa leading to the jejunal strangulation. J Gastroenterol 1998; 33: 734-8.

10. Decker G, du Plessis DJ. Lee McGregor's Synopsis of Surgical Anatomy. $12^{\text {th }}$ ed. Varghese Publishing House, Bombay 1986; 33-5.

11. Snell RS. Clinical anatomy by regions. $8^{\text {th }}$ ed. Lippincott Williams and Wilkins, New Delhi 2009; 208-9.

12. Romanes GJ. Cunningham's Mannual of Practical Anatomy. $5^{\text {th }}$ ed. Oxford University Press New York 1986; 121.

13. Lee TKY, Voon FCT, Chow KW, Teo NH. Unusual variant of right paraduodenal hernia. Aust NZ J Surg 1990; 60: 483-5.

14. Forgacs B, Istvan G, Sugar I, Ondrejka P. Uncommon case of incomplete left paraduodenal hernia. Magy Seb 2003; 56: 243-6.

15. Patterson JA, Tadros EG, Wilkinson AJ. An unusual case of left paraduodenal hernia. Int J Clin Pract 2001; 55: 649.

16. Ghahremani GG. Internal abdominal hernias. Surg Clin North Am 1984; 64: 393-406.

17. Armstrong O, Letessier E, Genier F, Lasserre P, Le Neel JC. Internal hernia: report of nine cases. Hernia 1997; 1: 143-5.

18. Selcuk D, Kantarci F, Ogut G, Korman U. Radiological evaluation of internal abdominal hernias. Turk J Gastroenterol 2005; 16: 57-64.

19. Kohli A, Choudhury HS, Rajput D. Internal hernia: a case report. Indian J Radiol Imaging 2006; 16: 563-6.

20. Hansmann GH, Morton SA. Intra-abdominal hernia: report of case and review of the literature. Arch Surg 1993; 39: 973-86.

21. Mall FP. Development of the human intestine and its position in the adult. Bull Johns Hopkins Hosp 1898; 9: 197-208.

22. Frazer TE, Robbins RF. On the factors concerned in causing rotation of the intestine in man. J Anat Physiol 1915; 50: 74-100. 